\title{
MSH2/BRCA1 expression as a DNA-repair signature predicting survival in early-stage lung cancer patients from the IFCT-0002 Phase 3 Trial
}

Guénaëlle Levallet ${ }^{1}$, Fatéméh Dubois ${ }^{2}$, Pierre Fouret ${ }^{3}$, Martine Antoine ${ }^{4}$, Solenn Brosseau $^{2,5,6}$, Emmanuel Bergot ${ }^{2,5}$, Michèle Beau-Faller ${ }^{7}$, Valérie Gounant ${ }^{6,8}$, Elisabeth Brambilla ${ }^{9}$, Didier Debieuvre ${ }^{10}$, Olivier Molinier ${ }^{11}$, Françoise GalateauSallé ${ }^{1}$, Julien Mazieres ${ }^{12}$, Elisabeth Quoix ${ }^{13}$, Jean-Louis Pujol ${ }^{14}$, Denis MoroSibilot ${ }^{15}$, Alexandra Langlais ${ }^{16}$, Franck Morin ${ }^{16}$, Virginie Westeel ${ }^{17}$ and Gérard Zalcman ${ }^{5,6,18,19}$

${ }^{1}$ Service d'Anatomie et Cytologie Pathologique, Centre Hospitalier Universitaire de Caen, Normandie Université, Caen, France

${ }^{2}$ Normandie Université; UMR 1086 INSERM, Caen, France

${ }^{3}$ Service d'Anatomie Pathologique, Pitié-Salpêtrière, AP-HP, Université Pierre et Marie Curie (UPMC), Paris, France

${ }^{4}$ Service d'Anatomie Pathologique, Hôpital Tenon, AP-HP, Université Pierre et Marie Curie (UPMC), Paris, France

${ }^{5}$ Service de Pneumologie et Oncologie Thoracique, Centre Hospitalier Universitaire de Caen, Normandie Université, Caen, cedex, France

${ }^{6}$ Service d'Oncologie Thoracique, Hôpital Bichat-Claude Bernard, AP-HP, Université Paris-Diderot, Paris, France

${ }^{7}$ Laboratoire de Biochimie et Biologie moléculaire, Hôpital de Hautepierre, Centre Hospitalier Universitaire de Strasbourg, Université de Strasbourg, BP426 Strasbourg, Cedex, France

${ }^{8}$ Service de Pneumologie, Hôpital Tenon, AP-HP, Université Pierre et Marie Curie (UPMC), Paris, France

${ }^{9}$ Service d'Anatomie Pathologique, Hôpital Albert Michallon, Centre Hospitalier Universitaire de Grenoble, La Tronche, France

${ }^{10}$ Service de Pneumologie, GHRMSA-Centre Hospitalier Eric Müller, Mulhouse, France

${ }^{11}$ Service de Pneumologie, Centre Hospitalier du Mans, Le Mans, France

${ }^{12}$ Service de Pneumologie, Hôpital Larrey, Centre Hospitalier Universitaire de Toulouse, Université de Toulouse III, Toulouse, France

${ }^{13}$ Service de Pneumologie, Nouvel Hôpital Civil, Hospices Civils de Strasbourg, Université de Strasbourg, BP426 Strasbourg, Cedex, France

14 Service de Pneumologie, Centre Hospitalier Universitaire Arnaud de Villeneuve, Université de Montpellier, Montpellier, France

15 Unité d'Oncologie Thoracique-Pneumologie, CHU de Grenoble, INSERM U823, Grenoble, France

${ }^{16}$ Intergroupe Francophone de Cancérologie Thoracique (IFCT), Paris, France

${ }^{17}$ Service de Pneumologie, Hôpital Jean-Minjoz, Centre Hospitalier Universitaire de Besançon, Université de Franche-Comté, Besançon, France

${ }^{18}$ CIC INSERM 1425-CLIP2 Paris-Nord, Hôpital Bichat-Claude Bernard, AP-HP, Paris, France

${ }^{19}$ On Behalf of the IFCT (Intergroupe Francophone de Cancérologie Thoracique)

Correspondence to: Gérard Zalcman, email: gerard.zalcman@aphp.fr

Keywords: non-small cell lung cancer; neo-adjuvant chemotherapy; MSH2; BRCA1; MGMT

Received: August 08, $2016 \quad$ Accepted: December 05, $2016 \quad$ Published: December 19, 2016

\section{ABSTRACT}

Introduction: DNA repair is a double-edged sword in lung carcinogenesis. When defective, it promotes genetic instability and accumulated genetic alterations. Conversely these defects could sensitize cancer cells to therapeutic agents inducing DNA breaks.

Methods: We used immunohistochemistry (IHC) to assess MSH2, XRCC5, and BRCA1 expression in 443 post-chemotherapy specimens from patients randomized 
in a Phase 3 trial, comparing two neoadjuvant regimens in 528 Stage I-II non-small cell lung cancer (NSCLC) patients (IFCT-0002). $0^{6}$ MGMT promoter gene methylation was analyzed in a subset of $\mathbf{2 0 8}$ patients of the same trial with available snap-frozen specimens.

Results: Median follow-up was from 90 months onwards. Only high BRCA1 (n = 221, hazard ratio $[\mathrm{HR}]=1.58,95 \%$ confidence interval $[\mathrm{CI}][1.07-2.34], p=0.02)$ and low MSH2 expression $(n=356, H R=1.52,95 \%$ CI $[1.11-2.08], p=0.008)$ significantly predicted better overall survival (OS) in univariate and multivariate analysis. A bootstrap re-sampling strategy distinguished three patient groups at high ( $n=55$, low BRCA1 and high MSH2, median OS >96 months, HR $=2.5,95 \%$ CI [1.454.33], $p=0.001)$, intermediate $(n=82$, median $O S=73.4 p=0.0596)$, and low (high BRCA1 and low MSH2, $n=67$, median OS $=$ ND, HR $=0.51,95 \%$ CI $[0.31-0.83], p=$ 0.006 ) risk of death.

Interpretation: DNA repair protein expression assessment identified three different groups of risk of death in early-stage lung cancer patients, according to their tumor MSH2 and BRCA1 expression levels. These results deserve prospective evaluation of MSH2/BRCA1 theranostic value in lung cancer patients treated with combinations of DNA-damaging chemotherapy and drugs targeting DNA repair, such as Poly(ADP-ribose) polymerase (PARP) inhibitors.

\section{INTRODUCTION}

Non-small cell lung cancers (NSCLC) account for approximately $85 \%$ of lung cancers. Despite curativeintent surgical resection, $20 \%$ of Stage I NSCLC patients die within 5 years, even following adjuvant chemotherapy, as NSCLC is highly metastatic and frequently chemoresistant [1]. However, complete tumor resection followed by adjuvant platinum-based chemotherapy plays a central role as a curative treatment for NSCLC. The benefit offered by adjuvant chemotherapy is modest, with an absolute improvement in 5-year overall survival (OS) ranging from 4 to $15 \%$ [2-4]. The French Cooperative Thoracic Intergroup (IFCT) initiated a large Phase 3 trial in 2001 to evaluate $i$ ) tolerance and efficacy of gemcitabinecisplatin versus paclitaxel-carboplatin perioperative chemotherapies; ii) the potential prognostic molecular biomarkers that could be helpful in defining therapeutic options and identifying genes/pathways that could be therapeutically targeted [5]. Lethal cisplatin-induced cell injury was extensively studied in vitro: cisplatin binds to DNA and induces adducts by covalent cross-linking between DNA strands, thereby inhibiting DNA replication and leading to cell apoptosis. Nevertheless, DNA repair mechanisms that reduce the effectiveness of cisplatin can ensure tumor-cell survival. The way to overcome this resistance is to combine cisplatin with a molecule inducing cell toxicity through alternative mechanisms, such as gemcitabine (2',2'-difluoro-2'-deoxycytidine), a nucleoside analogue, which interferes with DNA synthesis, or paclitaxel, a tubulin depolymerization-inhibitor, which alters the mitotic spindle by stabilizing microtubules. Combination platinum-based chemotherapy achieves 30$40 \%$ 1-year survival rates in Stage IV NSCLC and has proven superior to single agents or best supportive care in this setting. Gemcitabine inhibits the repair of cisplatininduced intrastrand adducts and interstrand cross-links [6]. Paclitaxel, by preventing microtubule depolymerisation, blocks the cell cycle progression in late G2-M phases. It has also been proposed that taxanes (docetaxel and paclitaxel) can induce DNA single-strand breaks (SSB), depending on the cell type $[7,8]$. The DNA damage repair process has crucial implications and, depending on their DNA repair efficiency, cancer cells can: $i$ ) interrupt the cell cycle to repair the DNA damage, ii) commence apoptosis, or iii) proceed with mitosis and cell proliferation without repairing the damage (while more molecular alterations accumulate). While the TP53 gene product has been shown as a key guardian of genome integrity [9], specific enzymes involved in genome integrity survey or DNA damage repair have been described, including key DNArepair proteins such as XRCC5, MSH2, BRCA1, and $\mathrm{O}^{6} \mathrm{MGMT}$, respectively involved in nucleotide excision repair (NER), base excision repair (BER), mismatch repair (MMR), or non-homologous end-joining (NHEJ) systems. These enzymes have been previously studied individually in NSCLC patients to assess their prognostic or predictive roles [10-23]. In response to the lack of consensus in the literature regarding the value of these enzymes' expression in tumors as predictive biomarkers in NSCLC [24], the IFCT 0002 Phase 3 randomized trial, with its large patient sample (528 patients enrolled between 2001 and 2005) and the homogeneity of their treatments, constituted further opportunity to assess whether or not XRCC5, MSH2, BRCA1, and $\mathrm{O}^{6} \mathrm{MGMT}$ represent reliable biomarkers in Stage I and II NSCLC patients, treated with taxane- or anti-metabolite-based perioperative chemotherapy. 


\section{RESULTS}

\section{DNA repair protein alterations and patient characteristics}

MSH2, XRCC5, and BRCA1 tumor immunostaining assays were technically possible for 356 (77.2\%), 396 (85.9\%), and $221(47.9 \%)$ patients with no complete histological response, respectively (Figure 1), revealing specific nuclear staining on a slide containing substantial tumor content, without extensive necrosis (Figure 2). Staining intensity varied markedly between lung-cancer samples and within the same slide, with strongly-stained clusters of tumor cells sometimes observed adjacent to weakly-stained tumor cells.

The characteristics of the IFCT-002 subset patients with IHC analyses have previously been described [25], presenting a mean age of 60.0 years (SD: 9.1, range: $35-76$ years) and Eastern Cooperative Oncology Group (ECOG) performance status (PS) of 0 (77.2-77.8\%). Only 9.7 to $10.2 \%$ of patients were "light" smokers $(<10$ packs per year), and 51.1 to $56.3 \%$ had non-squamous histology. The 396 patients with at least one DNA repair protein analysis available exhibited higher probability of having non-squamous NSCLC $(p<0.0001)$, though no significant difference was observed with the 132 patients without
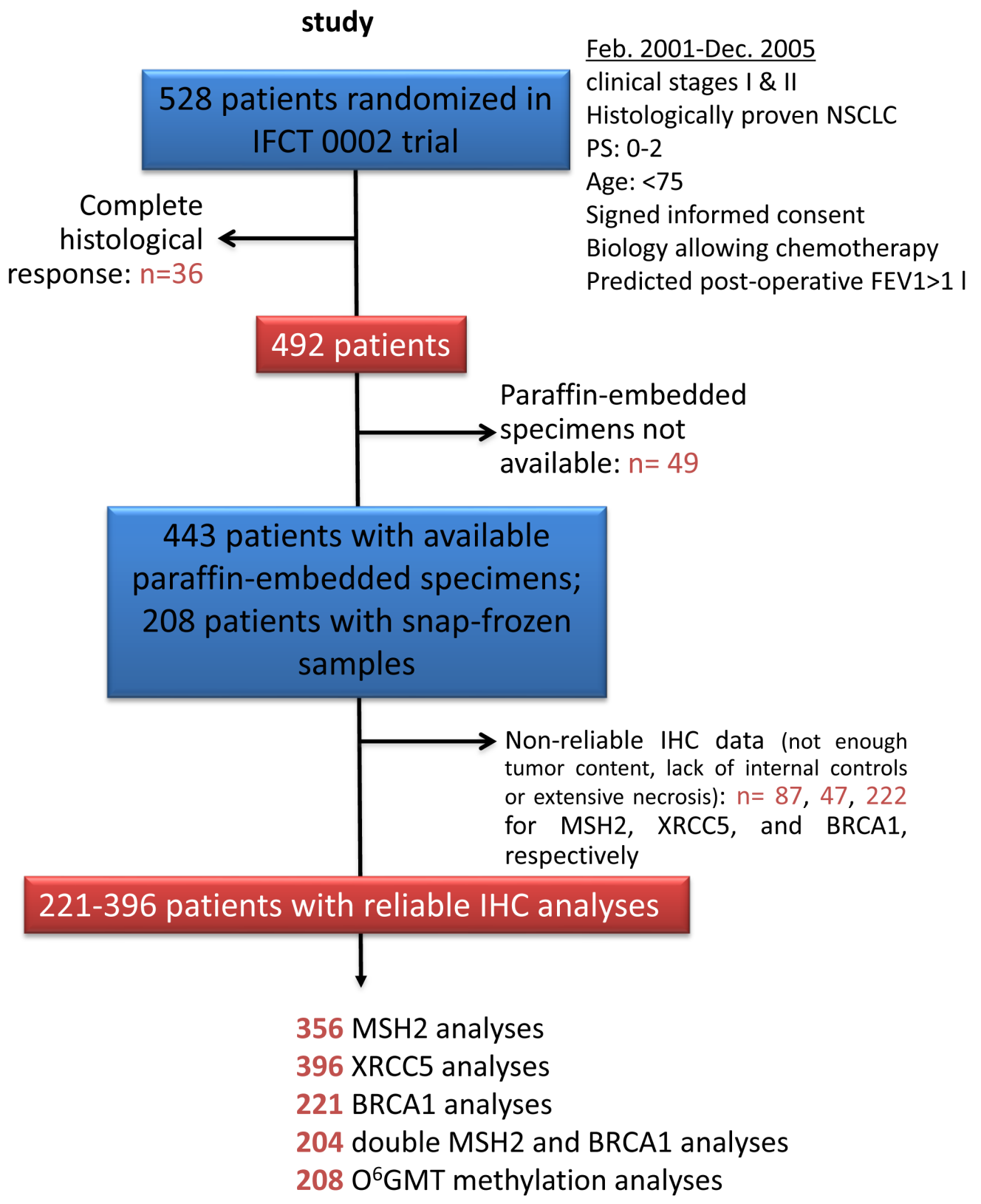

Figure 1: Patients and histological sample disposition in the Bio-IFCT 0002 study. 
DNA-repair protein IHC analyses for other characteristics. They especially exhibited similar OS and DFS values [25] Of the 208 snap-frozen specimens, $\mathrm{O}^{6} \mathrm{MGMT}$ promoter methylation was found in $14.9 \%$, and this subset was also characterized by a higher frequency of non-squamous histology $(46.2 \%$ vs. $32.8 \%, p=0.0051)$ in comparison with the rest of the population [26].
$\mathrm{O}^{6}$ MGMT methylation and XRCC5 expression do not influence survival

The average XRCC5 expression intensity score was $25.07 \pm 25.35$, with a median of 20 [10-30]. Neither $\mathrm{O}^{6} \mathrm{MGMT}$ methylation, nor XRCC5 expression either dichotomized at the median value or studied as a continuous variable, had any impact on OS and DFS of early-stage NSCLC patients in Cox models (data not shown).

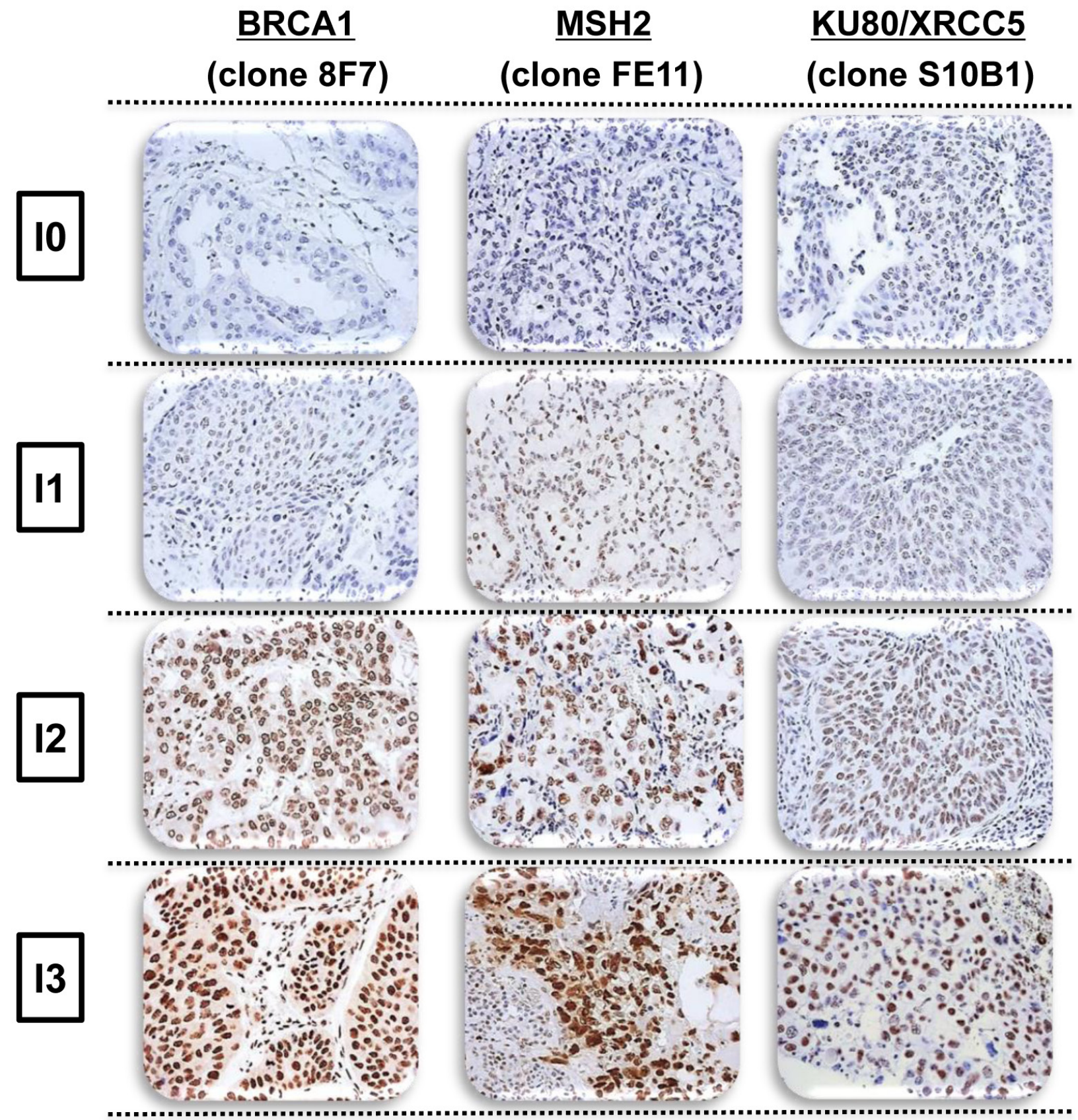

Figure 2: Representative intensity of BRCA1, MSH2, and XRCC5 immunostaining in non-small cell lung cancer, demonstrating negative $(I=0)$, weak $(I=1)$, moderate $(I=2)$, or strong $(I=3)$ staining. 
Table 1: MSH2/BRCA1 Immunostaining Characteristics

\begin{tabular}{|c|c|c|c|c|c|c|c|c|c|}
\hline Characteristics & $\begin{array}{l}\text { MSH2 }<\text { Q2 } \\
n=167\end{array}$ & $\begin{array}{l}\text { MSH2 } \geq \text { Q2 } \\
n=189\end{array}$ & $p$ & $\begin{array}{l}\text { BRCA1 }<\text { Q2 } \\
n=92\end{array}$ & $\begin{array}{l}\text { BRCA1 } \geq \text { Q2 } \\
n=129\end{array}$ & $p$ & $\begin{array}{l}\text { MSH2 }<\text { Q2 + } \\
\text { BRCA1 } \geq \text { Q2 } \\
n=67\end{array}$ & $\begin{array}{l}\text { Other } \\
n=137\end{array}$ & $p$ \\
\hline \multicolumn{10}{|l|}{ Gender } \\
\hline Male & $129(77.2 \%)$ & $152(80.4 \%)$ & 0.4631 & $72(78.3 \%)$ & $98(76 \%)$ & 0.6901 & $48(71.6 \%)$ & $106(77.4 \%)$ & 0.3715 \\
\hline Female & $38(22.8 \%)$ & $37(19.6 \%)$ & & $20(21.7 \%)$ & $31(24 \%)$ & & $19(28.4 \%)$ & $31(22.6 \%)$ & \\
\hline $\begin{array}{l}\text { Age at inclusion } \\
\leq 60 \text { years old } \\
>60 \text { years old } \\
\end{array}$ & $\begin{array}{l}91(54.5 \%) \\
76(45.5 \%) \\
\end{array}$ & $\begin{array}{l}77(40.7 \%) \\
112(59.3 \%) \\
\end{array}$ & 0.0095 & $\begin{array}{l}42(45.7 \%) \\
50(54.3 \%) \\
\end{array}$ & $\begin{array}{l}68(52.7 \%) \\
61(47.3 \%) \\
\end{array}$ & 0.3007 & $\begin{array}{l}38(56.7 \%) \\
29(43.3 \%) \\
\end{array}$ & $\begin{array}{l}64(46.7 \%) \\
73(53.3 \%) \\
\end{array}$ & 0.1796 \\
\hline $\begin{array}{l}\text { Pack-year * } \\
\leq 10 \\
>10\end{array}$ & $\begin{array}{l}19(11.4 \%) \\
147(88.6 \%) \\
\end{array}$ & $\begin{array}{l}17(9.1 \%) \\
170(90.1 \%)\end{array}$ & 0.4656 & $\begin{array}{l}9(9.9 \%) \\
82(90.1 \%)\end{array}$ & $\begin{array}{l}12(9.5 \%) \\
115(90.5 \%)\end{array}$ & 0.9133 & $\begin{array}{l}9(13.6 \%) \\
57(86.4 \%)\end{array}$ & $\begin{array}{l}11(8.1 \%) \\
125(91.9 \%) \\
\end{array}$ & 0.2156 \\
\hline \multicolumn{10}{|l|}{ Performance status } \\
\hline 0 & $139(83.2 \%)$ & $136(72 \%)$ & 0.0113 & $67(72.8 \%)$ & $105(81.4 \%)$ & 0.1306 & $57(85.1 \%)$ & $99(72.3 \%)$ & 0.0428 \\
\hline 1 or 2 & $28(16.8 \%)$ & $53(28 \%)$ & & $25(27.2 \%)$ & $24(18.6 \%)$ & & $10(14.9 \%)$ & $38(27.7 \%)$ & \\
\hline \multicolumn{10}{|l|}{ Histology } \\
\hline $\mathrm{SCC}$ & $58(34.7 \%)$ & $82(43.4 \%)$ & 0.0952 & $31(33.7 \%)$ & $50(38.8 \%)$ & 0.4412 & $23(34.3 \%)$ & $55(40.1 \%)$ & 0.4220 \\
\hline Non-SCC & $109(65.3 \%)$ & $107(56.6 \%)$ & & $61(66.3 \%)$ & $79(61.2 \%)$ & & $44(65.7 \%)$ & $82(59.9 \%)$ & \\
\hline \multicolumn{10}{|l|}{$\operatorname{Arm}(\mathrm{ITT})$} \\
\hline gemcitabine 4 cycles PRE & $41(24.5 \%)$ & $47(24.9 \%)$ & \multirow{4}{*}{0.1944} & $17(18.5 \%)$ & $33(25.6 \%)$ & \multirow{4}{*}{0.5934} & $18(26.9 \%)$ & $28(20.4 \%)$ & \multirow{4}{*}{0.746} \\
\hline gemcitabine 2 cycles PERI & $35(21.0 \%)$ & $51(27.0 \%)$ & & $23(25.0 \%)$ & $33(25.6 \%)$ & & $15(22.4 \%)$ & $37(27.0 \%)$ & \\
\hline paclitaxel 4 cycles PRE & $38(22.8 \%)$ & $49(25.9 \%)$ & & $25(27.2 \%)$ & $32(24.8 \%)$ & & $17(25.4 \%)$ & $36(26.3 \%)$ & \\
\hline paclitaxel 2 cycles PERI & $53(31.7 \%)$ & $42(22.2 \%)$ & & $27(29.3 \%)$ & $31(24.0 \%)$ & & $17(25.4 \%)$ & $36(26.3 \%)$ & \\
\hline \multicolumn{10}{|l|}{ Number of cycles received } \\
\hline$\leq 2$ & $99(59.3 \%)$ & $106(56.1 \%)$ & 0.5425 & $53(57.6 \%)$ & $68(52.7 \%)$ & 0.4711 & $37(55.2 \%)$ & $75(54.7 \%)$ & 0.9485 \\
\hline$>2$ & $68(40.7 \%)$ & $83(43.9 \%)$ & & $39(42.4 \%)$ & $61(47.3 \%)$ & & $30(44.8 \%)$ & $62(45.3 \%)$ & \\
\hline \multicolumn{10}{|l|}{ Stage } \\
\hline $0, \mathrm{I}$ & $91(54.5 \%)$ & $106(56.1 \%)$ & 0.7628 & $41(44.6 \%)$ & $73(56.6 \%)$ & 0.0779 & $40(59.7 \%)$ & $64(46.7 \%)$ & 0.0814 \\
\hline II, III, IV & $76(45.5 \%)$ & $83(43.9 \%)$ & & $51(55.4 \%)$ & $56(43.4 \%)$ & & $27(40.3 \%)$ & $73(53.3 \%)$ & \\
\hline \multicolumn{10}{|l|}{$\mathrm{cT}$} \\
\hline $\mathrm{T} 1$ & $112(67.1 \%)$ & $116(61.4 \%)$ & 0.2642 & $60(65.2 \%)$ & $82(63.6 \%)$ & 0.8006 & $45(67.2 \%)$ & $83(60.6 \%)$ & 0.3613 \\
\hline $\mathrm{T} 2$ ou $\mathrm{T} 3$ & $55(32.9 \%)$ & $73(38.6 \%)$ & & $32(34.8 \%)$ & $47(36.4 \%)$ & & $22(32.8 \%)$ & $54(39.4 \%)$ & \\
\hline
\end{tabular}

*information missing for 3 patients

\section{High MSH2 expression significantly predicts worse overall survival}

The average MSH2 expression intensity score was $231.03 \pm 69.09$, with a median of 255 [180-300]. MSH2 staining was first studied as a continuous variable. Low MSH2 staining was more frequent in young $(p=0.03)$ and ECOG PS 0 patients $(p=0.008)$ (Table 1$)$. MSH2 status did not significantly differ according to gender, treatment arm, number of chemotherapy cycles, histological differentiation, pathological stage, smoking status, or clinical T. MSH2 staining, analyzed as a continuous variable, and tested for a 1 unit increase of IHC score (from 0 to 300), significantly predicted OS in univariate analysis $(\mathrm{HR}=1.003,95 \% \mathrm{CI}[1.000-1.005] ; p=0.020)$ and multivariate backward model (adjusted $\mathrm{HR}=1.003$, 95\% CI [1.000-1.005]; $p=0.03$ ), including all variables with a p-value $<0.2$ in the univariate analysis (gender, Stage I vs. II, and squamous $v s$. non-squamous histology) (Table 2).

Subsequent statistical analyses, correlating MSH2 expression with DFS or OS, have dichotomized the MSH2 score, with low (score below the median of 255, $n=167$ [46.9\%]) and high MSH2 expression (score above the median, $n=189$ [53.1\%]). Patients whose tumor samples expressed low MSH2 had not reached the median OS at the time of follow-up, compared to patients whose tumor samples expressed high MSH2 (60.5 months [44.6-77.8]) (Figure 3, left panel), in both univariate (HR $=0.65[0.48$ to 0.89$], \log$-rank $p=0.007)$ and multivariate analysis (Cox model, including stage, histology, and gender, adjusted HR $=0.66,95 \%$ CI $[0.48-0.90], p=0.008$ ) (Table 2). DFS was not significantly affected according to MSH2 level (Table 2 and Figure 3, right panel). Finally, MSH2 influence on prognosis did not differ according 
Table 2: MSH2 Expression, Progression-Free Survival, and Overall Survival in Patients from the Bio-IFCT 0002 Trial

\begin{tabular}{|c|c|c|c|c|c|c|c|c|c|c|}
\hline Outcome & & $\begin{array}{l}\text { MSH2 }<\text { Q2 } \\
n=167\end{array}$ & \begin{tabular}{|ll} 
MSH2 & $\geq$ \\
Q2 & \\
$n=189$ & \\
\end{tabular} & $p$ & $\begin{array}{l}\text { BRCA1 }<\text { Q2 } \\
n=92\end{array}$ & $\begin{array}{l}\text { BRCA1 } \geq \text { Q2 } \\
n=129\end{array}$ & $\mathbf{p}$ & $\begin{array}{l}\text { MSH2 < Q2 + } \\
\text { BRCA1 } \geq \text { Q2 } \\
n=67\end{array}$ & \begin{tabular}{|l|} 
Other \\
$n=137$ \\
\end{tabular} & $p$ \\
\hline \multirow[t]{4}{*}{ PFS } & Number of events & 97 & 120 & & 92 & 69 & & 32 & 86 & \\
\hline & Median (month) & 36.1 [24.1-61.1] & $\begin{array}{l}35.4 \\
46.4]\end{array}[23.2-$ & & $16.2[13.3-36.0]$ & 54.2 [39.8-ND] & & ND & $\begin{array}{l}32.5[16.0- \\
49.1]\end{array}$ & \\
\hline & $\operatorname{HR}(95 \% \mathrm{CI})$ & \begin{tabular}{|l}
0.88 \\
{$[0.67-1.14]$}
\end{tabular} & 1 & 0.33 & $1.44[1.01-2.04]$ & 1 & 0.04 & $\left.\begin{array}{l}0.62 \\
0.94]\end{array}\right]$ & 1 & 0.02 \\
\hline & Adj. HR $(95 \% \mathrm{CI})$ & - & - & - & - & - & - & $\begin{array}{l}0.63 \\
0.95] \quad[0.42-\end{array}$ & 1 & 0.03 \\
\hline \multirow[t]{4}{*}{ OS } & Number of events & 66 & 102 & & 49 & 51 & & 21 & 70 & \\
\hline & Median (month) & ND & $\begin{array}{l}60.5 \\
77.8]\end{array}$ & & 47.1 [28.1-ND] & 90.6 [73.5-ND] & & ND & $\begin{array}{l}66.5 \\
\text { ND] }\end{array}$ & \\
\hline & $\operatorname{HR}(95 \% \mathrm{CI})$ & 0.65 [0.48-0.89] & 1 & 0.007 & $1.58[1.07-2.34]$ & 1 & 0.02 & $\left.\begin{array}{l}0.50 \\
0.82]\end{array}\right][0.31-$ & 1 & 0.006 \\
\hline & Adj. HR ${ }^{\ddagger}(95 \% \mathrm{CI})$ & $0.66[0.48-0.90]$ & 1 & 0.008 & $\begin{array}{l}1.58 \quad[1.07- \\
2.34]\end{array}$ & 1 & 0.02 & $\begin{array}{l}0.51 \\
0.83] \quad[0.31-\end{array}$ & 1 & 0.006 \\
\hline
\end{tabular}

I HR was adjusted according to histology, stage, and gender for OS; HR was adjusted according to histology and stage for PFS.

to treatment arm (paclitaxel versus gemcitabine), since no significant interaction was observed between MSH2 expression status and treatment arm for DFS prediction (data not shown). For external validation of our data, we used kpm.plot.com online software, computing the MSH2 mRNA prognostic analyses in 681 Stage I-to-III patients, with gene-expression data and OS information downloaded from the GEO (Affymetrix microarrays only),
EGA, and TCGA databases (2015 database release) [27]. OS analysis was dichotomized according to the median value (Figure 4) and revealed high MSH2 mRNA content to also be significantly associated with poorer survival in this series of patients $(\mathrm{HR}=1.72 ; 95 \% \mathrm{CI}[1.39-2.12], p$ $\left.=3.8 \times 10^{-7}\right)$.

\section{A) Overall survival}

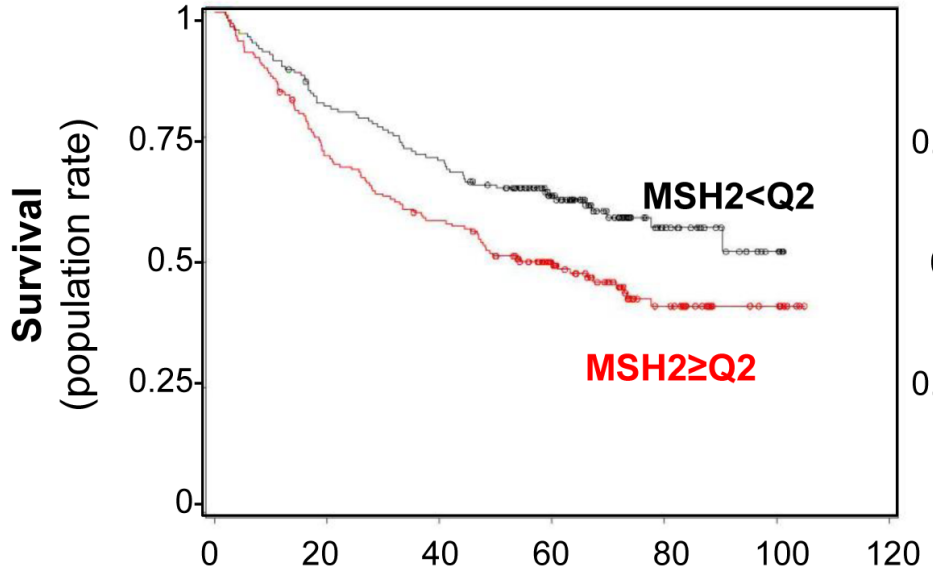

Months

\section{B) Progression-free survival}

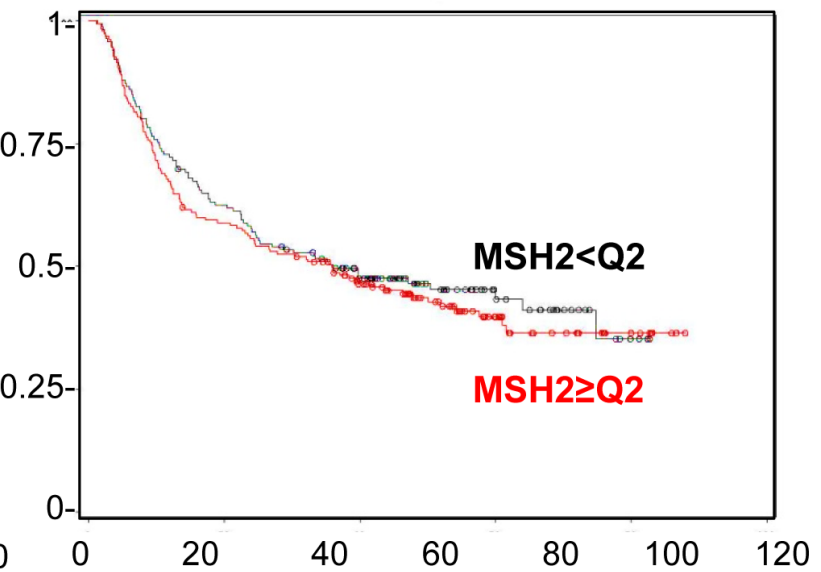

Figure 3: MSH2 level impact on both overall survival (A) and progression-free (B) survival rates. A. Overall survival curve for the 356 patients in the bio-IFCT 0002 trial, according to MSH2 expression. B. Progression-free survival rate curve for the 356 patients in the bio-IFCT 0002 trial, according to MSH2 expression. 
Table 3: Sequence of Primers Used for PCR

\begin{tabular}{|c|c|}
\hline Gene name & Primer sequence (5'-3') \\
\hline BRCA1 & $\begin{array}{l}\text { Forward: ACAGCTGTGTGGTGCTTCTGTG } \\
\text { Reverse: CATTGTCCTCTGTCCAGGCATC }\end{array}$ \\
\hline MSH2 & $\begin{array}{l}\text { Forward: GGAGGAGAGACTGCTGGAGA } \\
\text { Reverse: TCCCTTTTTGCCTTTCAACA }\end{array}$ \\
\hline XRCC5 & $\begin{array}{l}\text { Forward: GAAGGTGAAGATGGGTTGGA } \\
\text { Reverse: AATTGGAGCCAATGGTCAGT }\end{array}$ \\
\hline S16 & $\begin{array}{l}\text { Forward: CTGGAGCCAGTTCTGCTTCT } \\
\text { Reverse: TCTGGTAATAGGCCACCAGG }\end{array}$ \\
\hline
\end{tabular}

\section{MSH2 expression is not altered by chemotherapy}

Given that patient tumor samples were collected following neoadjuvant chemotherapy, and since we were not able to compare such samples with the diagnostic biopsies obtained before surgery, we raised the question of chemotherapy's influence on MSH2 expression. We used cell lines reproducing the most frequent molecular alterations in NSCLC: H1299 (p53 deletion, RASSF1A methylation), H1650 (EGF-R mutation, RASSF1A methylation, p53 mutation, CDKN2A deletion), H1975 (EGF-R mutation, p53 mutation, R273H, PI3K mutation, CDKN2A deletion), and A549 (RASSF1A methylation, RasSer12, CDKN2A deletion, Lkb1/STK11 mutation). We also used two isogenic non-tumorigenic, immortalized, bronchial cells lines with a low number of molecular alterations (CDK4 and hTERT lentiviral-mediated overexpression), HBEC-3 (p16/Rb block), and HBEC3RasV12 (p16/Rb block, Ras mutation).

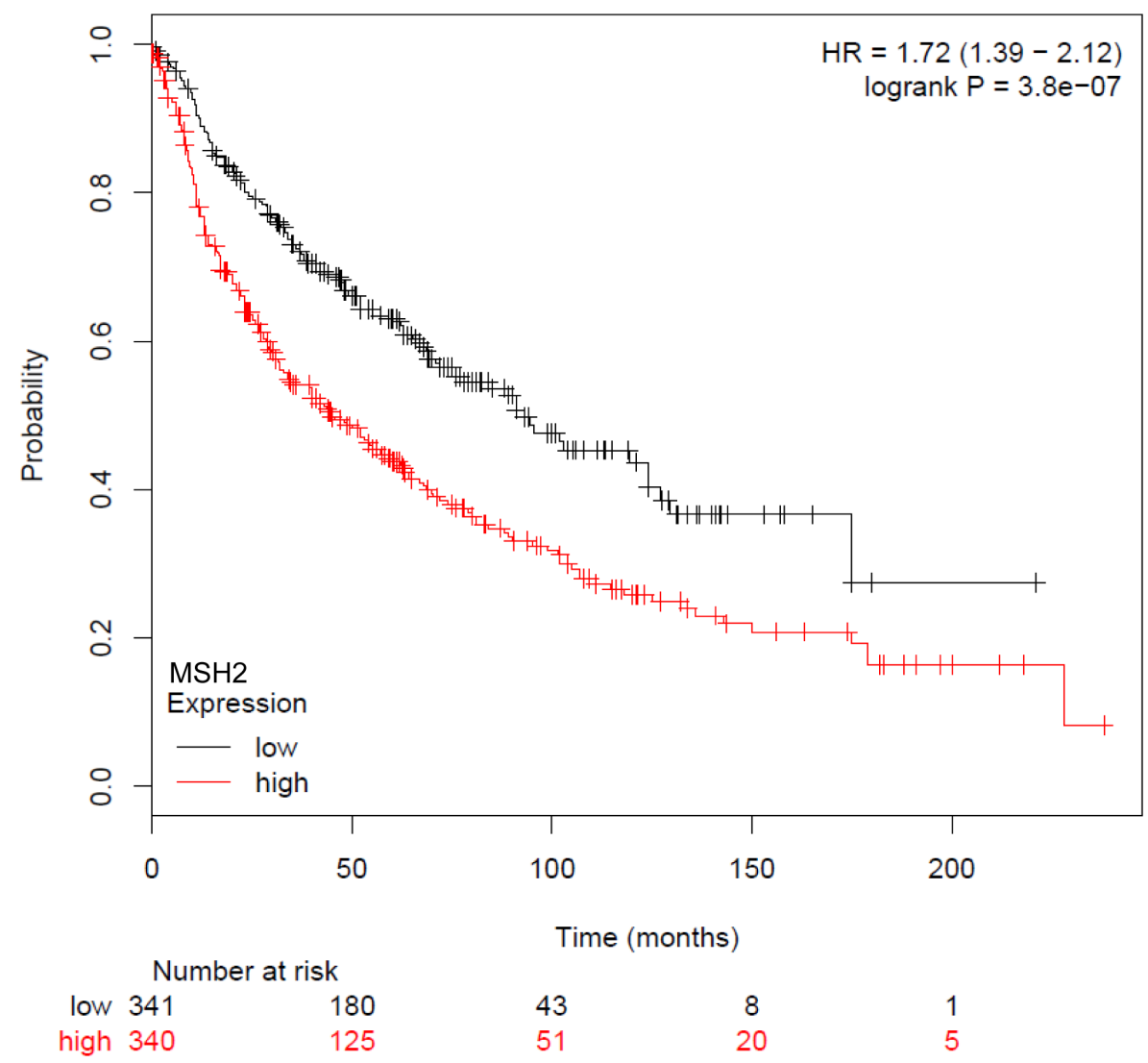

Figure 4: Kaplan-Meier overall survival curves according to MSH2 mRNA, from GEO (Affymetrix microarrays only), EGA, and TCGA databases (2015 database release), using kpm.plot.com online software, in 681 NSCLC Stage I-III patients. 
In line with the clinical trial findings (i.e., high MSH2 expression correlating with poor OS), we found that the cell lines expressing the highest MSH2 mRNA basal content were the H1299 and A549 cell lines (Figure 5), namely those with the highest tumorigenic potential when xenografted in nude mice [28-30]. Cells were incubated in the presence of cisplatin/gemcitabine or cisplatin/ paclitaxel, as detailed in Materials and Methods. Treatment efficacy was evaluated by measuring DNA fragmentation and immunolabeling cytochrome $\mathrm{C}$ as readouts for cell apoptosis. In the HBEC-3 non-tumorigenic cell line, both cisplatin/paclitaxel and cisplatin/gemcitabine treatments significantly increased DNA fragmentation 2.5- to 2.8fold (Figure 6A, t-test, treated cells vs. control cells, $p$ $<0.05$ ), as in the HBEC-3-RasV12, A549, H1650, and H1299 cells (data not shown). Both treatments increased cytochrome c cytoplasmic signal nearly 2 -fold in these cells (Figure 6B), again demonstrating chemotherapyinduced apoptosis in such conditions in non-tumorigenic and tumorigenic cell lines. Conversely, chemotherapy had no impact on MSH2 protein content, as demonstrated by the stable MSH2/actin ratios (Figure 6C). It has been suggested that such chemotherapy regimens could induce p38/Mitogen-Activated Protein Kina se14 (MAPK14) activity, a stress-activated signaling, which contributes to the cytotoxic effect of cisplatin [31-33]. Here, we reported that, despite the observed phospho-p38 increase (as a readout for p38 activation) induced by cisplatin (shown here for A549 cells in Figure 7), the MSH2 protein levels were not altered by chemotherapy (Figures 6C and 7) in HBEC-3 (non-tumorigenic), H1650 (EGFR mutation), and A549 (K-Ras mutation) cell lines, as with H1299 cell lines (data not shown). In the A549 cells, blocking p38 MAPK activation using pharmacological inhibitor SB202190 did not modify MSH2 expression, while A549 cells contained an inactivating STK11/LkB1 mutation, with Lkb1 inactivation leading to p38 hyper-activation [34].These in vitro results suggest that neo-adjuvant chemotherapy did not alter MSH2 expression, and that MSH2 status was independent of $\mathrm{p} 38$ activity in tumors from patients of the Bio-IFCT0002 trial. In line with this data, we did not find that phospho-p38 intensity staining had any influence on OS and DFS of patients from the Bio-IFCT0002 trial, nor did treatment arm (data not shown).

\section{A new signature for high-risk recurrence and death}

BRCA1 is another extensively studied DNA-repair protein. Allelic loss, mutations, and gene methylation have been shown to alter BRCA1 protein content. We also report that low BRCA1 expression significantly predicted both worse OS and PFS in early-stage NSCLC.

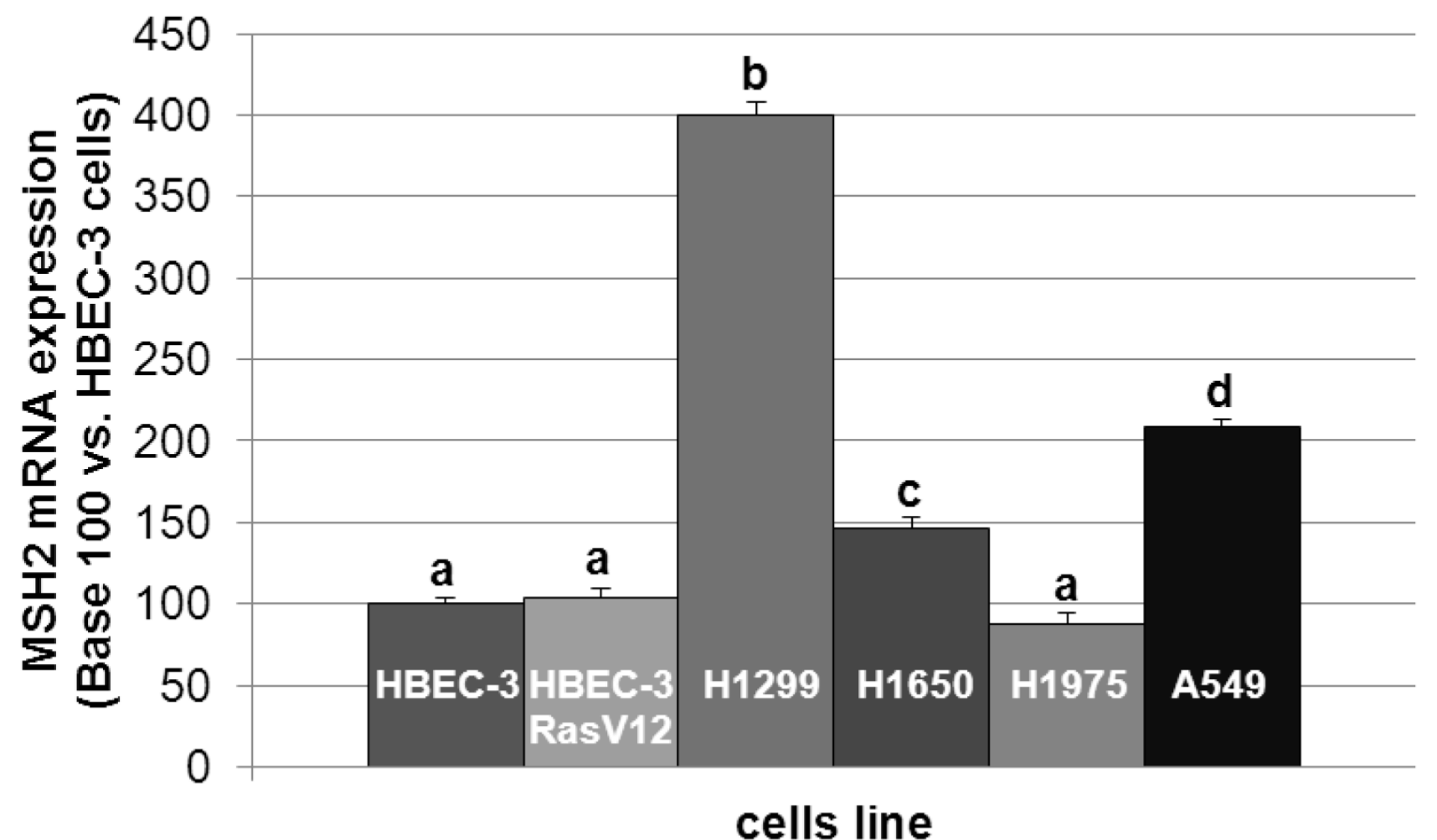

Figure 5: MSH2 mRNA expression level in lung cancer cell lines. The different letters above the histograms represent the significant differences between them (one-way ANOVA, following post-hoc test of Fisher's LSD, $p<0.05$ ). 


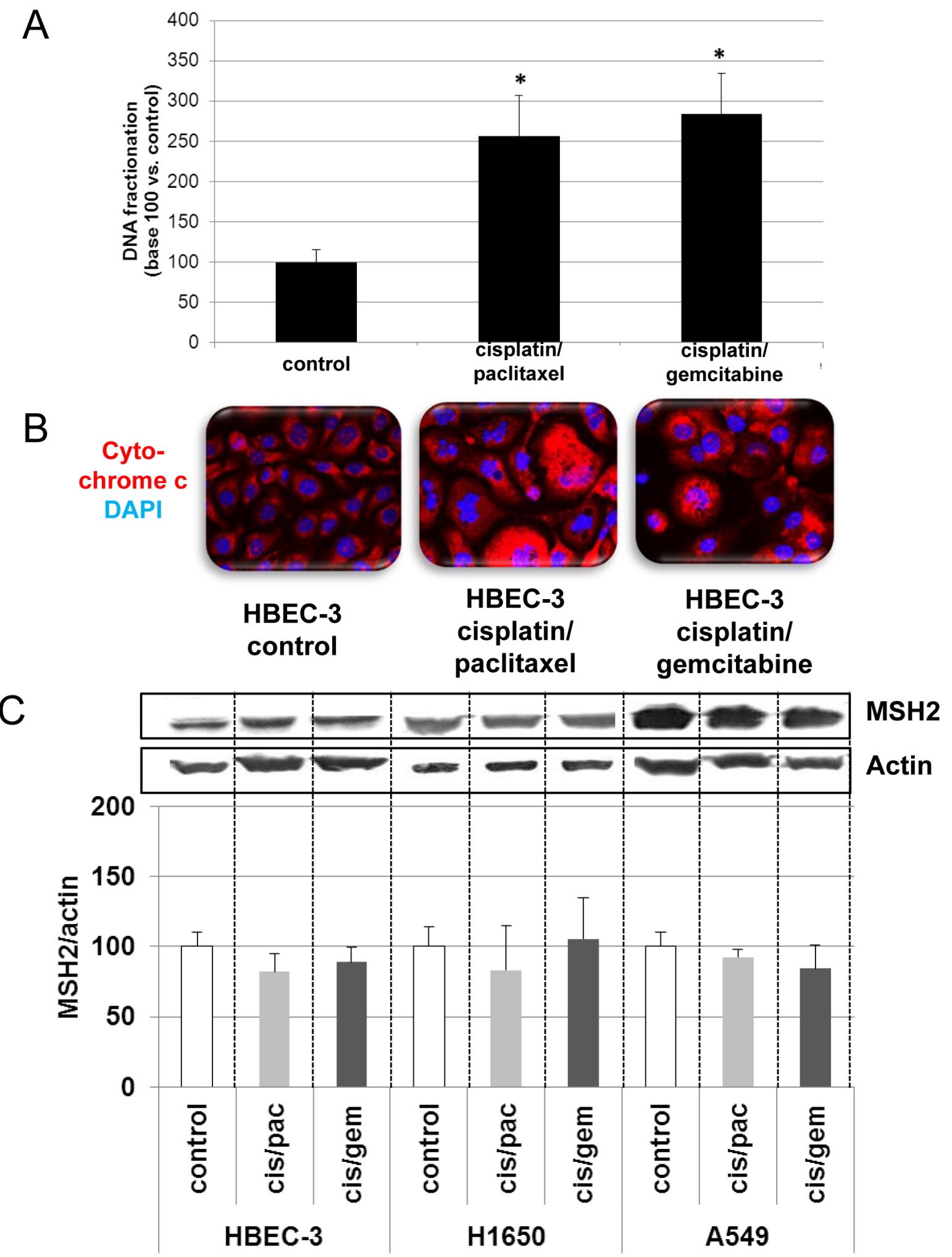

Figure 6: Effects of cisplatin/paclitaxel or cisplatin/gemcitabine treatment on DNA fragmentation (A), cytochrome C release (B), and MSH2 expression (C) in bronchial cell lines. At 50\% confluence, the bronchial cell lines were incubated or not (control) with cisplatin $(2 \mu \mathrm{M})$ for $3 \mathrm{~h}$ before incubation for $48 \mathrm{~h}$ with paclitaxel $(10 \mathrm{nM})$ or gemcitabine $(250 \mathrm{nM})$. Following treatment, DNA fragmentation, cytochrome $\mathrm{C}$ release, and MSH2 levels were measured. Results were expressed in base 100, with 100 attributed to the control cells $\left(\mathrm{n}=3\right.$, t-test $v s$. control cells, $\left.{ }^{*} p<0.05\right)$. 
The average BRCA1 expression intensity score was $103.98 \pm 74.07$, with a median of 100 [30-160]. As with MSH2, BRCA1 status was not significantly affected by the clinical parameters, either when low or high according to dichotomization at median value (Table 1).

To assess the influence of BRCA1 expression on DFS and OS, expression IHC scores were dichotomized at median value, with low score defined as below the median value of 100 (92 [41.6\%] patients) and high score as above (129 [58.4\%] patients). BRCA1 low H-score predicted worse OS in our Cox model adjusted for variables significantly affecting $\mathrm{OS}$ (adjusted $\mathrm{HR}=1.58$ $95 \%$ CI [1.07-2.34], $p=0.02$ ) while leading to worse DFS $(\mathrm{HR}=1.4495 \%$ CI [1.01-2.04], $p=0.04)$, though not in a Cox model adjusted for histology and stage (Table 2 and Figure 8, A and B left panel, respectively). No significant interaction between BRCA1 expression status and treatment arm was observed for DFS or OS prediction (data not shown).

In our experiments, the $8 \mathrm{~F} 7$ clone did not enable reliable western blot (WB) analyses in lung cancer cell line extracts, despite claims that it functions for WB application. We then checked for any chemotherapy effects on cells in BRCA1 mRNA species, as measured by semi-quantitative qRT-PCR. We found only a slight increase in BRCA1 mRNA in non-tumorigenic cells following treatment by both doublets in HBEC-3 cells, potentiated by $\mathrm{p} 38$ inhibition, and only after paclitaxelbased doublet exposure in HBEC-3-RasV12 cells (Figure 9). In lung cancer cells, there was no variation (A549) or a slight decrease (H1975, H1650, H1299) of BRCA1 mRNA upon chemotherapy doublet treatment, with no potentiation by the p38 inhibitor (Figure 9).

Taking into account both the MSH2 and BRCA1 analyses, we subsequently tried to establish whether a combined expression signature of these two DNA repair proteins influenced the outcome of patients from the Bio-IFCT0002 trial. Among the 396 specimens, BRCA1 and MSH2 were simultaneously available in 204. Low MSH2 combined with high BRCA1 expression was more frequent in low-ECOG PS patients ( $p=0.04$ ) (Table 1). The proportion of low MSH2 cases was $50 \%$ (55 cases out of 110 ) in the low BRCA1 group, and 50\% (55 cases out of 110) in the high BRCA1 group.
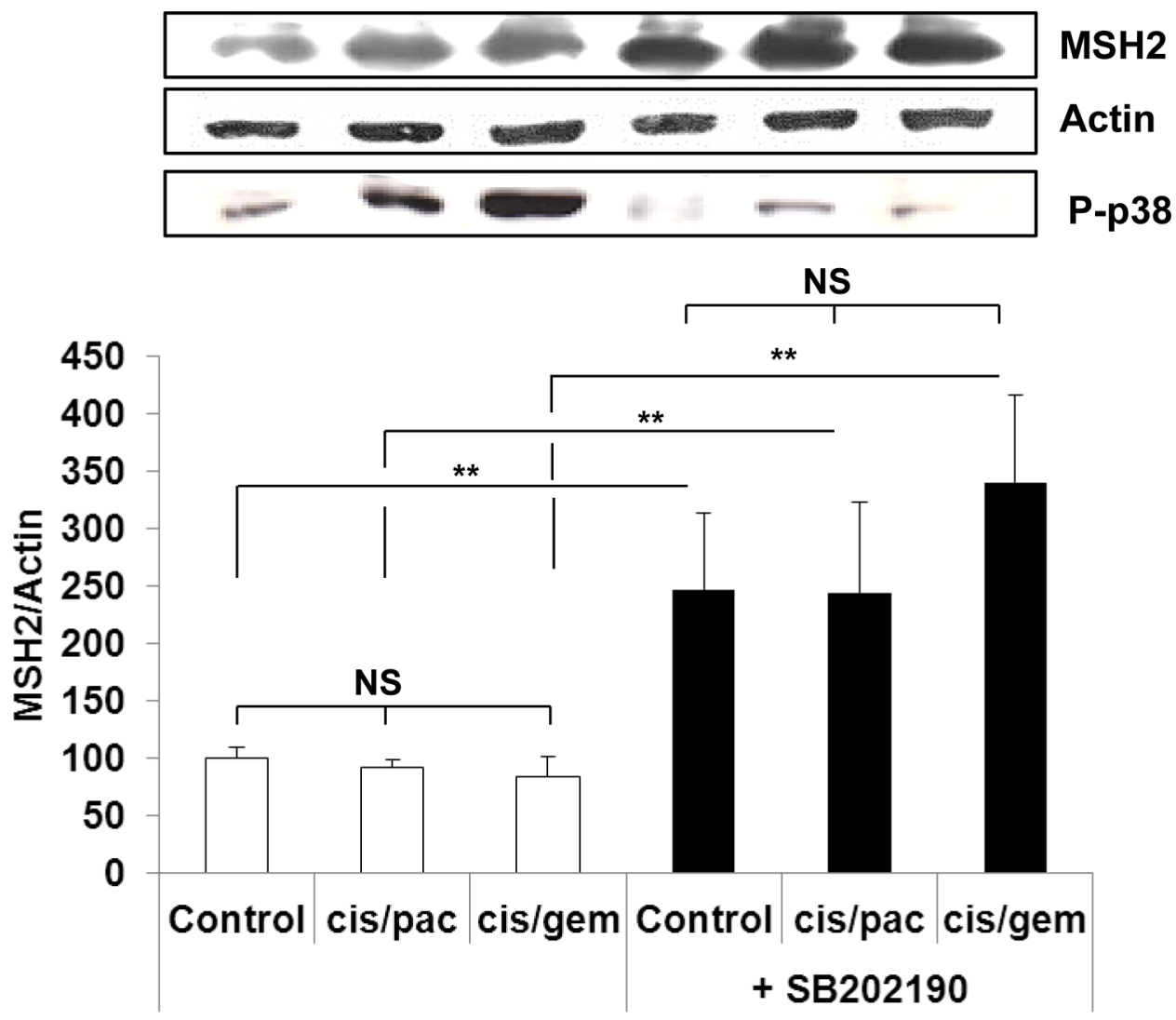

Figure 7: MSH2 expression following p38 blocking or cisplatin/paclitaxel or cisplatin/gemcitabine treatment in A549 cells. At 50\% confluence, bronchial cell lines were incubated or not (control) for 1 h with SB202190 $(20 \mu \mathrm{M})$ then with cisplatin $(2 \mu \mathrm{M})$ for $3 \mathrm{~h}$ before incubation for $48 \mathrm{~h}$ with paclitaxel $(10 \mathrm{nM})$ or gemcitabine $(250 \mathrm{nM})$. Following treatment, MSH2 and phospho-p38 levels were measured by WB. Results were expressed in base 100, with 100 attributed to the control cells, i.e., A549 without any treatment (one-way ANOVA, following post-hoc test of Fisher's LSD, $* *: p<0.01$, NS: non-significant). 
A
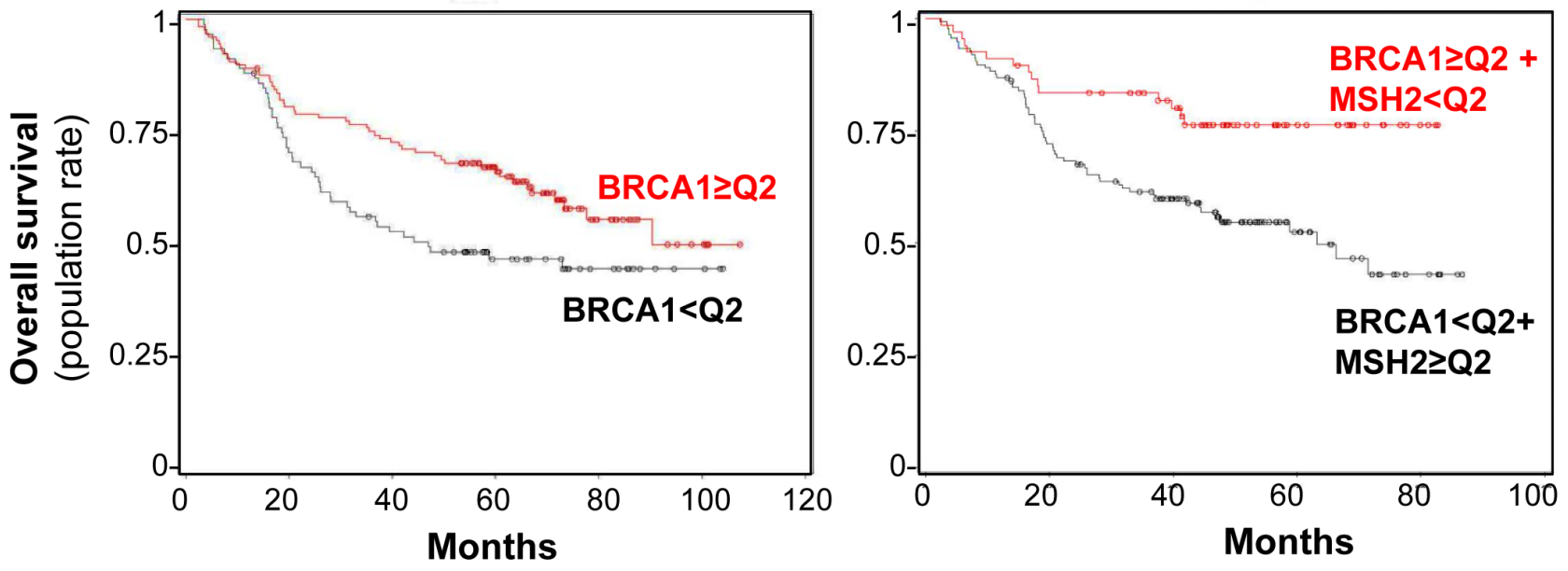

B
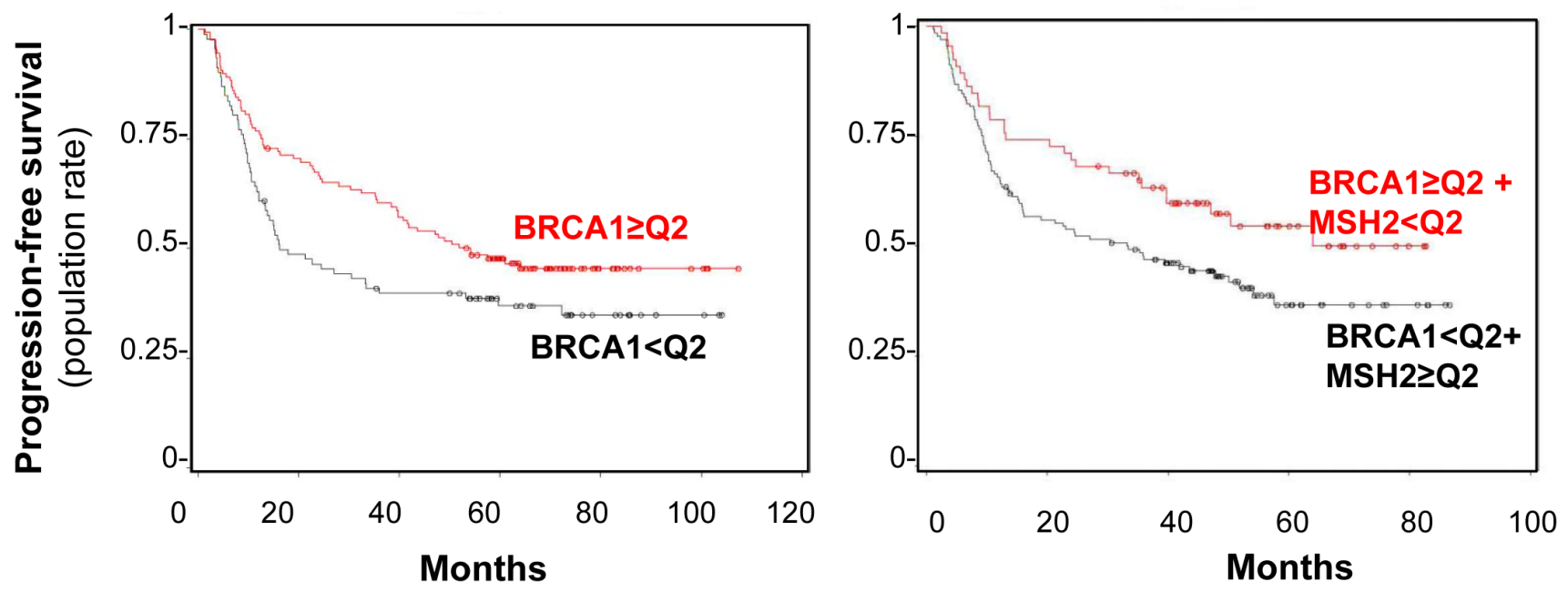

C

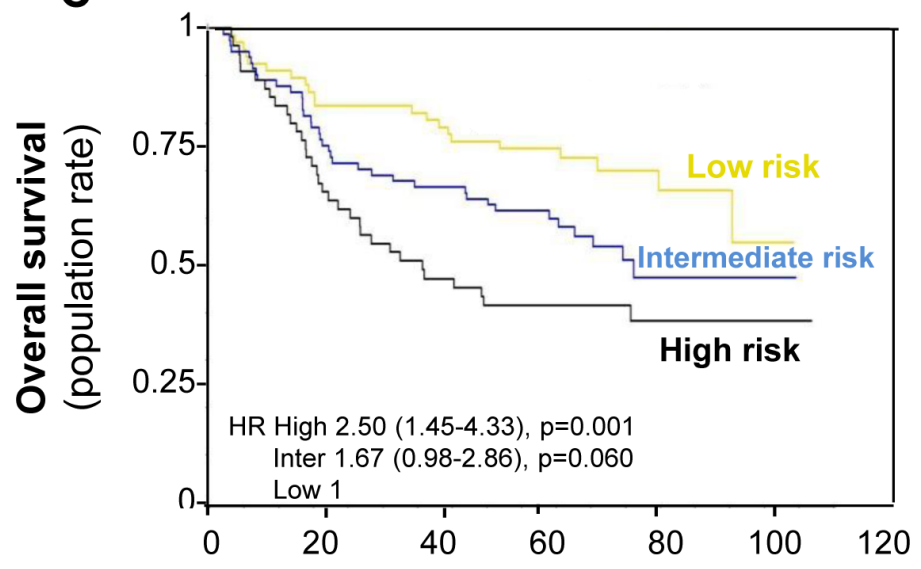

Months

Figure 8: BRCA1 level impact on both overall survival (A) and progression-free (B) survival rates in combination with MSH2 level or alone. A. Overall survival curve for the 221 patients in the bio-IFCT 0002 trial, according to BRCA1 with or without MSH2 expression. B. Progression-free survival rate curve for the 221 patients in the bio-IFCT 0002 trial, according to BRCA1 with or without MSH2 expression. C. Identification of three groups of early-lung cancer patients from low to high risk of recurrence, according to BRCA1 and MSH2 level. "High" risk of death: low BRCA1/ high MSH2 ( $n=55)$; "low": high BRCA1/low MSH2 ( $n=67)$; "intermediate" for other combinations $(n=82)$. 
In both univariate and multivariate analysis, Cox models showed that high BRCA1 and low MSH2 expression appears to predict longer OS $(\mathrm{HR}=0.51$ [0.31-0.83], $p=0.006)$ and DFS (HR $=0.63$ [0.42-0.95], $p=0.03)$, adjusted for clinical variables significantly influencing OS (histology, pathological stage, and gender) or DFS (histology and pathological stage), respectively
(Table 2) (Figure 8, A and B right panel, respectively). A prognostic score was then constructed according to Cox models and validated by a bootstrap re-sampling strategy, which accurately defined three groups of early-lung cancer patients at low to high risk of recurrence and death despite perioperative cisplatin-based chemotherapy. These three patient groups were at "high risk" of death when

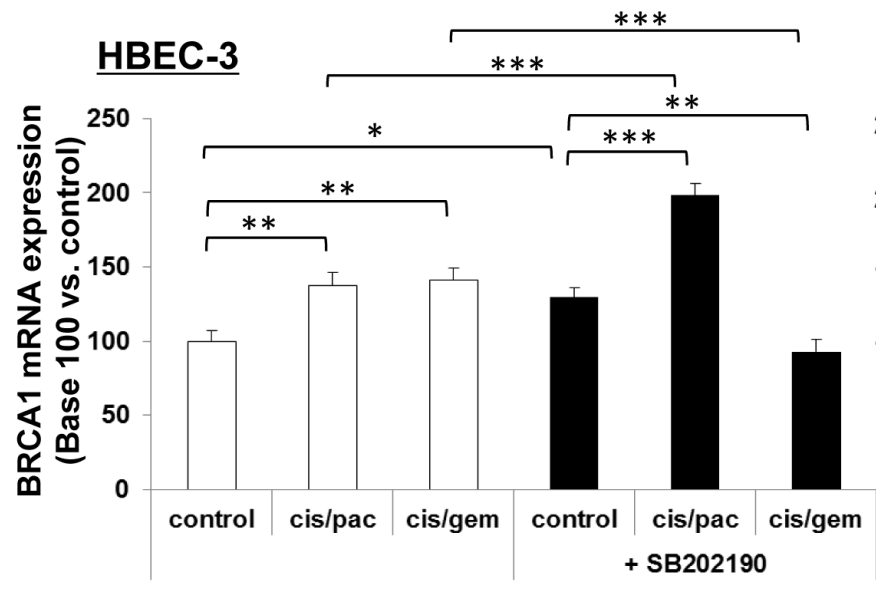

\section{HBEC-3 RasV12}

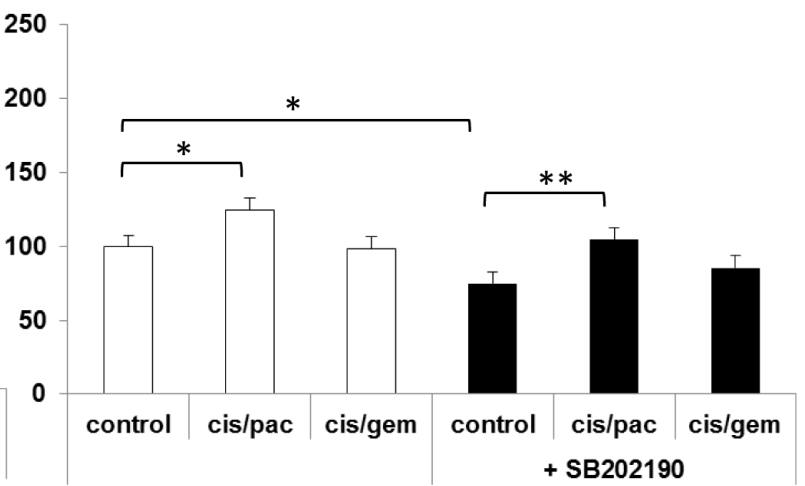

A549

\section{H1975}
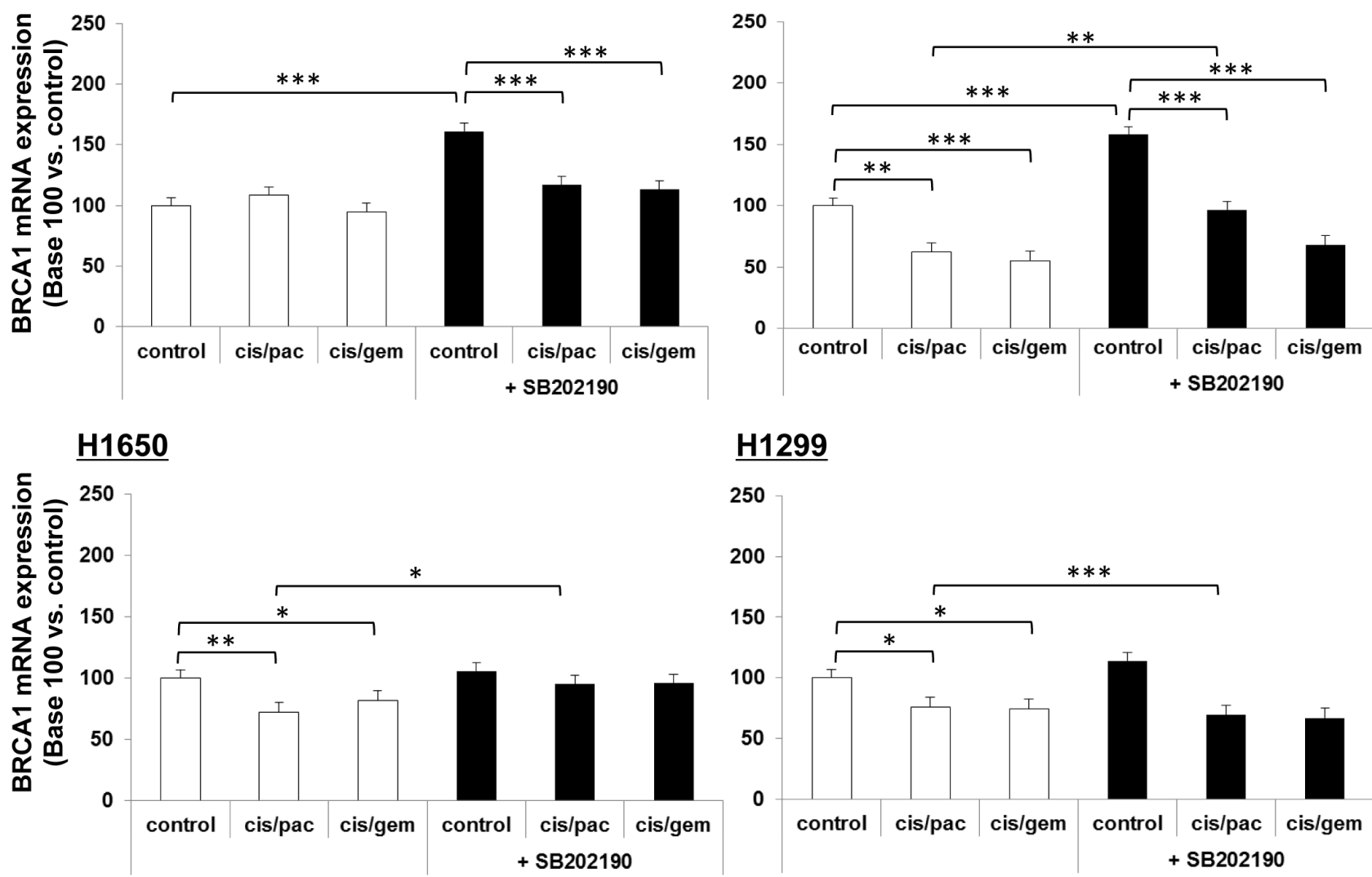

\section{H1299}

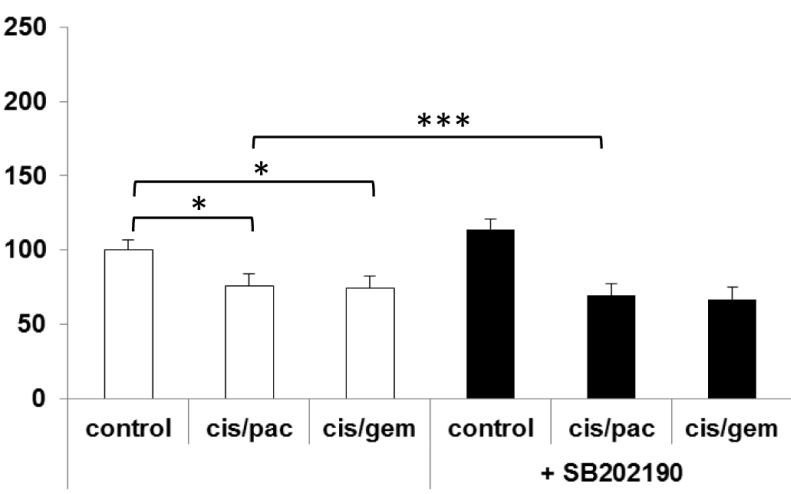

Figure 9: BRCA1 mRNA expression following p38 blocking or cisplatin/paclitaxel or cisplatin/gemcitabine treatment, in immortalized lung or lung cancer cell lines. At 50\% confluence, cell lines were incubated or not (control) for $1 \mathrm{~h}$ with SB202190 $(20 \mu \mathrm{M})$ then with cisplatin $(2 \mu \mathrm{M})$ for $3 \mathrm{~h}$ before incubation for $48 \mathrm{~h}$ with paclitaxel $(10 \mathrm{nM})$ or gemcitabine $(250 \mathrm{nM})$. Following treatment, BRCA1 mRNA expression was assayed by qRT-PCR. Results were expressed in base 100, with 100 attributed to the control cells, i.e., cells without any treatment for each cell line (one-way ANOVA, following post-hoc test of Fisher's LSD, **: $p<0.01$, NS: non-significant). 
BRCA1 was low and MSH2 high $(n=55$, median OS $>96$ months, $\mathrm{HR}=2.5,95 \%$ CI [1.45-4.33], $p=0.001)$, at "low risk" when BRCA1 was high and MSH2 low (n $=67$, median $\mathrm{OS}=36.8$ months $\mathrm{ND}, \mathrm{HR}=0.512 .5,95 \%$ CI [0.31-0.83], $p=0.006)$, and at "intermediate risk" in other combinations $(n=82$, median $\mathrm{OS}=73.4 p=0.0596)$ (Figure 8C).

Finally, no significant interaction between low BRCA1 and high MSH2 expression status and treatment arm was observed in terms of DFS or OS prediction, again revealing this signature to be prognostic yet not predictive.

\section{DISCUSSION}

We hereby report that the expression of two crucial DNA repair proteins, MSH2 and BRCA1, in early-stage NSCLC samples from patients who received preoperative platinum-based doublets in a Phase 3 trial, defines three distinct groups of high, intermediate, and low risk of death, according to their respective tumor expression of MSH2 and BRCA1.

Though the role of MSH2 is well established in several cancers, especially hereditary nonpolyposis colon cancer, with tumor immunohistochemistry used as a reliable tool for HNPCC its involvement in NSCLC is not yet clearly defined, with no report of any $\mathrm{MSH} 2$ gene mutations in such cancer subtype $[35,36]$. Kamal et al. studied MSH2 protein expression using IHC in 673 tumor tissue paraffin-embedded samples from patients with resected NSCLC who received adjuvant platinum-based chemotherapy, reporting that $\mathrm{MSH} 2$ protein expression was a predictive factor [16]. In their work, high MSH2 expression was less frequent than in ours (38\% vs. 53.1\%, respectively), although different methods were used (high expression defined as a staining intensity $>2$, while we used a composite score). Patients with high MSH2 expression had an OS of 42 months (vs. 58 months for the others). In the current bio-IFCT-0002 study, patients with high MSH2 expression have an OS of 60 months (vs. over 100 months for the others). Several differences between these two studies must be emphasized: i) the sample size (356 vs. 673 for Kamal's study), ii) the patients' treatments (carboplatin/paclitaxel or cisplatin/ gemcitabine combination in the IFCT-0002 trial, cisplatinbased adjuvant chemotherapy with a large percentage of older second-generation drugs in the IALT trial), iii) the chemotherapy administration schedule (patients in the IFCT-0002 trial received neo-adjuvant chemotherapy and tissue block samples were extracted during surgery, while IALT trial patients only received adjuvant chemotherapy). Nevertheless, our findings are in line with those of Kamal's study: high MSH2 expression is a very strong prognostic factor.

We also report that using an additional marker may provide a better prognostic evaluation. Several DNA repair proteins could be used as prognostic or predictive biomarkers of response to chemotherapy or radiation in lung cancer patients. Kamal et al., for example, reported that combining both MSH2 and ERCC1 markers achieved better prediction of long-term chemotherapy benefit than using either one alone [16]. However, the ERCC1 monoclonal $8 \mathrm{~F} 1$ antibody was disqualified in a more recent report from the same team due to specificity issues [37].

In the Bio-IFCT0002 study, high MSH2 expression combined with low BRCA1 expression indicated a risk of recurrence and death in early-stage lung cancer patients treated with perioperative chemotherapy. BRCA1 gene expression could be affected by allelic loss, gene mutations altering mRNA stability or promoter hypermethylation. We were not able to directly assess the influence of chemotherapy on tumor BRCA1 expression, but the lack of BRCA1 mRNA increase in bronchial cells or lung cancer cell lines on chemotherapy exposure indicates that neo-adjuvant chemotherapy had no influence on BRCA1 content in our patients, and that such treatment cannot account for the prognostic discrepancies with previously published papers. Indeed, in contrast to our findings, low BRCA1 expression was previously reported to be a potential biomarker for predicting the benefit of perioperative cisplatin-based chemotherapy [38]. Furthermore, high BRCA1 mRNA levels correlated with shorter OS in another study on chemo-naive patients with resected NSCLC [13]. All these findings were generated by means of mRNA analyses differing from ours using IHC analysis of protein expression. Other striking differences between our study and the literature are the proportion of squamous-cell carcinomas (SCC). SCC accounted for $36.5 \%$ of patients in the Bio-IFCT0002 trial versus $47 \%$ in the Taron study and $74 \%$ in the Rosell study $[13,38]$. Moreover, Rosell reported a significantly higher content of BRCA1 mRNA in SCCs than in adenocarcinomas. Both of these studies also included Stage III patients (17.5\% and $81 \%$, respectively), rendering any comparison with the Bio-IFCT 0002 dataset challenging. The largest dataset of BRCA1 and MSH2 IHC (769 samples) was derived from the IALT adjuvant study [39]. which used tissue microarrays (TMAs) and digital-based automated scoring. In this series, comprising 57\% SCC patients, BRCA1 expression was below the median expression score value in $65 \%$ of patients, vs. $41 \%$ in our series, suggesting significant differences in IHC scoring between the studies. It could, alternatively, indicate discrepancies in the influence of SCC proportion (57\%), since the IALT study also reported higher BRCA1 expression in SCC samples. In their large patient sample, neither MSH2 nor BRCA1 were found to significantly influence OS, either in SCC or in the whole group, despite $\mathrm{MSH} 2$ expression being found to significantly predict DFS in SCC patients, though not in the whole population. These results contrast with those of earlier studies by the Rosell group (analyzing BRCA1 mRNA expression), thus suggesting the importance of 
epigenetic BRCA1 expression. The authors also contradict their own previously-published data (analyzing MSH2 IHC), suggesting the influence of TMA sampling biases, as compared with whole tumor section analysis [16] or suggesting some versatility of DNA-repair markers.

Whether combining MSH2 and BRCA1 markers could override conflicting data from the literature still requires confirmation in a prospective independent homogenous series of early-stage patients, as such discrepancies often result from differences in methodology and populations. However, this combination could create a more powerful prognostic model, as shown by the resampling internal validation of our MSH2/BRCA1 dual signature.

Our data thus demonstrate that specific biomarkers for DNA repair pathways can provide important prognostic information. Whether such information can guide oncologists in therapeutic decisions requires further prospective validation and the MSH2/BRCA1 signature deserves validation in patients included in the future neoadjuvant clinical trials. The pharmacological modulation of DNA repair proteins has been suggested to increase the efficacy of DNA-interacting chemotherapy and radiotherapy, favoring tumor cell death primed by singleor double-strand DNA breaks [43]. Our data also provide a rationale to assess whether Poly(ADP-ribose) polymerase (PARP) inhibitors would increase chemotherapy efficacy in lung cancer patients with abnormal MSH2 or BRCA1 content, by a synthetic lethality mechanism.

\section{MATERIALS AND METHODS}

\section{Patients and the Bio-IFCT 0002 trial}

Between 2001 and 2005, the IFCT 0002 Phase 3 trial accrued 528 patients [5], comparing two platinumbased perioperative chemotherapy regimens, gemcitabine plus cisplatin or paclitaxel plus carboplatin, in Stage I or II NSCLC patients. Specific informed consent was obtained for biological studies (Bio-IFCT 0002) and approved by the trial's appointed ethics committee (CPPRB of the Besançon University Hospital, France). Diagnostic biopsy samples before surgery were not available for comparison with post-operative samples used in this study since obtained by bronchial endoscopy and CT-guided trans-thoracic fine-needle aspiration biopsy, thus smallsized and used for routine histological characterization by standard immunohistochemistry (TTF1, p40, CK7, CK20 immunohistochemistry and HES, PAS-diastase colorations).

\section{Immunohistochemistry (IHC) and scoring}

Paraffin-embedded surgical blocks were collected from 491 patients with incomplete histological response following neo-adjuvant chemotherapy. In this series, 7.2\% of patients had complete histological response and only $461 / 528$ (87\%) specimens were available for IHC analysis [25]. Tumor paraffin-embedded blocks were processed as previously described [25]. Slides were incubated with primary antibody against BRCA1 (AbCam, clone 8F7, 1/400 - 20 min RT), MSH2 (Calbiochem, clone FE11, 1/200 - 60 min RT), or XRCC5 (Genetex, clone S10B1, 1/900 - 30 min RT), then revealed using the Novolink (Menarini, for BRCA1, MSH2) or Envision (Dako, for XRCC5) kits. Positive internal controls were systematically evaluated (normal epithelial cells). All slides were examined by one of four expert thoracic pathologists depending on the protein under analysis, one molecular biologist, and one clinician, all blinded to individual patient data. The staining intensity of each tumor-cell cluster, scored as 0 (negative), 1 (weak), 2 (moderate), or 3 (strong), at 40x magnification, was established by consensus among the three analysts (representative examples shown in Figure 1). The same overall IHC score was calculated for each staining by taking the sum of the staining intensity (0-3) multiplied by the distribution ( $0-100 \%)$, giving an $\mathrm{H}$ score between 0 and 300 .

\section{O6MGMT promoter hypermethylation assay}

Snap-frozen specimens were collected in centers possessing the facilities to bank frozen tissues at $-80^{\circ} \mathrm{C}$. The DNA yield from 208 samples was sufficient for independent polymerase chain reaction (PCR) amplifications for multiple molecular analyses, as previously published [26]. $\mathrm{O}^{6} \mathrm{MGMT}$ hypermethylation promoter was assayed by methylation-specific PCR (MS-PCR), with genomic DNA bisulfite modification performed using the Epitect ${ }^{\mathrm{TM}}$ kit (Qiagen, France), and PCR amplification as reported by Esteller et al. [41] PCR products were loaded onto 5\% agarose gels, stained with Gel-Red ${ }^{\mathrm{TM}}$ (Interchim, France) and visualized under UV light.

\section{Cell culture and treatments}

Isogenic immortalized human bronchial epithelial cells (HBEC) HBEC-3 and HBEC-3-RasG12V bronchial cells (42] were grown in KFSM (keratinocyte serum-free medium) supplemented with EGFr $(0.2 \mathrm{ng} / \mathrm{ml})$ and BPE (bovine pituitary extracts, $25 \mu \mathrm{g} / \mathrm{ml}$ ) at $37^{\circ} \mathrm{C}$ in $5 \% \mathrm{CO}_{2}$. The tumorigenic epithelial lung cancer-derived cells H1299, H1650, H1975, and A549 were from the American 
Type Culture Collection and used in early passages after reception. At $50 \%$ confluence, the cells were incubated or not for 1 h with a p38 inhibitor, SB202190 (20 $\mu \mathrm{M})$, then cisplatin $(2 \mu \mathrm{M})$ was added for $3 \mathrm{~h}$ before $48 \mathrm{~h}$ of incubation with gemcitabine $(250 \mathrm{nM})$ or paclitaxel $(10 \mathrm{nM})$.

\section{DNAfragmentation}

DNA fragmentation was assayed following the manufacturer's procedures (Cell Death Detection ELISA plus $\mathrm{kit}^{\mathrm{TM}}$; Roche), with the cytoplasmic cell fraction used in the enzyme-linked immunosorbent assay, and 405nm optical density (OD, absorbance) was determined using a micro-plate reader following 5-min incubation with peroxidase substrate.

\section{Reverse transcription-quantitative real-time-PCR (RT-PCR)}

Following extraction, RT-PCR was performed with each primer set (Table 3), as previously described [25]. RT-PCR data was normalized to the human S16. Relative quantification was calculated using the delta-deltaCt method.

\section{Immunoblotting}

The antibodies used for IHC were the same as those used for WB. Whole-cell protein extracts were analyzed by WB, as previously described [25], with proteins detected with an enhanced chemiluminescence technique using the ECL kit ${ }^{\mathrm{TM}}$ (Promega).

\section{Immunofluorescence and image analysis}

We performed immunofluorescence studies using the cytochrome $\mathrm{C}$ primary antibody from BD Biosciences diluted in $1 \%$ bovine serum albumin (BSA)/phosphate buffered saline (PBS) containing $0.3 \%$ triton $\mathrm{X}-100$, added overnight at $1 / 50$ and $4^{\circ} \mathrm{C}$. The Alexa Fluor 555 (Invitrogen) secondary antibody was added for $1 \mathrm{~h}$ at room temperature in 1\% BSA/PBS. Coverslips were mounted with DAPI (Santa CruzTM) and image captured with high-throughput confocal microscopy (FluoView FV1000, Olympus $\left.^{\mathrm{TM}}\right)$.

\section{Statistical analysis}

The Bio-IFCT0002 study was a pre-planned ancillary and exploratory study. The characteristics of patients positive or not for each DNA repair protein on IHC, or exhibiting molecular alterations, were compared using chi-squared tests or Fisher's exact tests for qualitative variables, and Student's $t$-tests for quantitative variables. Associations between DNA repair protein expression and clinical characteristics were evaluated using chi-squared tests, Fisher's exact tests, or Student's $t$-tests.

Prognosis values for disease-free survival (DFS) and overall survival (OS), based on IHC scores, were assessed using Cox models. Interaction tests were used to evaluate predictive values. IHC scores were first studied as continuous variables ranging from 0 to 300 . Median follow-up was estimated using the reverse Kaplan-Meier method. Multivariate Cox models were used to adjust for patients' characteristics associated with the corresponding outcomes (DFS or OS) at $p<0.20$ in univariate analysis. In all models, the IHC scores were dichotomized (negative/positive) as indicated by a fractional polynomial analysis, the median value being selected in both MSH1 and BRCA1 analyses by this methodology. A twostep bootstrap re-sampling analysis was performed to validate the prognostic model, testing its stability and reproducibility [43]. The data was analyzed with SPSS software SPSS for Windows Version 15.0, Chicago, IL: SPSS, Inc., 2006), the mfp package of R software (mfp: multivariable fractional polynomials, $\mathrm{R}$ package Version 1.4.0, original by Gareth Ambler and modified by Axel Benner, 2007) and SAS software, Version 9.3 (SAS Institute Inc., Cary, NC, USA). The in vitro data are presented as mean \pm standard error of the mean (SEM) of the three independent experiments. Statistical differences were assessed by Student's paired $t$-test for single comparisons or one-way analysis of variance (ANOVA), followed by Dunnett's multiple comparison test, to compare each condition from a given experiment with a single control (siNeg) (GraphPad Software, Inc. USA). Statistical significance was set at $p \leq 0.05$.

\section{CONFLICTS OF INTEREST}

The authors declare no financial conflicts of interest.

\section{REFERENCES}

1. Goldstraw P, Chansky K, Crowley J, Rami-Porta R, Asamura H, Eberhardt WE, Nicholson AG, Groome P, Mitchell A, Bolejack V. The IASLC Lung Cancer Staging Project: Proposals for Revision of the TNM Stage Groupings in the Forthcoming (Eighth) Edition of the TNM Classification for Lung Cancer. J Thorac Oncol 2016;11(1):39-51.

2. NSCLC Meta-analysis Collaborative Group. Preoperative chemotherapy for non-small-cell lung cancer: a systematic review and meta-analysis of individual participant data. Lancet 2014;383(9928):1561-71.

3. Burdett S, Stewart LA, Rydzewska L. A systematic review and meta-analysis of the literature: chemotherapy and 
surgery versus surgery alone in non-small cell lung cancer. J Thorac Oncol 2006;1(7):611-21.

4. Hamada C, Tanaka F, Ohta M, Fujimura S, Kodama K, Imaizumi M, Wada H. Meta-analysis of postoperative adjuvant chemotherapy with tegafur-uracil in non-small-cell lung cancer. J Clin Oncol 2005;23(22):4999-5006.

5. Westeel V, Quoix E, Puyraveau M, Lavole A, Braun D, Laporte S, Bigay-Game L, Pujol JL, Ozenne G, Riviere A, Douillard JY, Lebeau B, Debieuvre, et al. A randomised trial comparing preoperative to perioperative chemotherapy in early-stage non-small-cell lung cancer (IFCT 0002 trial). Eur J Cancer 2013;49(12):2654-64.

6. Moufarij MA, Phillips DR, Cullinane C. Gemcitabine potentiates cisplatin cytotoxicity and inhibits repair of cisplatin-DNA damage in ovarian cancer cell lines. Mol Pharmacol 2003;63(4):862-9.

7. Digue L, Orsiere T, De Meo M, Mattei MG, Depetris D, Duffaud F, Favre R, Botta A. Evaluation of the genotoxic activity of paclitaxel by the in vitro micronucleus test in combination with fluorescent in situ hybridization of a DNA centromeric probe and the alkaline single cell gel electrophoresis technique (comet assay) in human T-lymphocytes. Environ Mol Mutagen 1999;34(4):269-78.

8. Das GC, Holiday D, Gallardo R, Haas C. Taxol-induced cell cycle arrest and apoptosis: dose-response relationship in lung cancer cells of different wild-type p53 status and under isogenic condition. Cancer Lett 2001;165(2):147-53.

9. Lane DP. Cancer. p53, guardian of the genome. Nature 1992;358(6381):15-6.

10. Bhattacharyya A, Ear US, Koller BH, Weichselbaum RR, Bishop DK. The breast cancer susceptibility gene BRCA1 is required for subnuclear assembly of Rad51 and survival following treatment with the DNA cross-linking agent cisplatin. J Biol Chem 2000;275(31):23899-903.

11. Quinn JE, Kennedy RD, Mullan PB, Gilmore PM, Carty M, Johnston PG, Harkin DP. BRCA1 functions as a differential modulator of chemotherapy-induced apoptosis. Cancer Res 2003;63(19):6221-8.

12. Olaussen KA, Dunant A, Fouret P, Brambilla E, Andre F, Haddad V, Taranchon E, Filipits M, Pirker R, Popper HH, Stahel R, Sabatier L, Pignon JP, et al. DNA repair by ERCC1 in non-small-cell lung cancer and cisplatin-based adjuvant chemotherapy. N Engl J Med 2006;355(10):98391.

13. Rosell R, Skrzypski M, Jassem E, Taron M, Bartolucci R, Sanchez JJ, Mendez P, Chaib I, Perez-Roca L, Szymanowska A, Rzyman W, Puma F, Kobierska Gulida $\mathrm{G}$, et al. BRCA1: a novel prognostic factor in resected nonsmall-cell lung cancer. PLoS One 2007;2(11):e1129.

14. Wachters FM, Wong LS, Timens W, Kampinga HH, Groen HJ. ERCC1, hRad51, and BRCA1 protein expression in relation to tumour response and survival of stage III/IV NSCLC patients treated with chemotherapy. Lung Cancer 2005;50(2):211-9.
15. Ceppi P, Volante M, Novello S, Rapa I, Danenberg KD, Danenberg PV, Cambieri A, Selvaggi G, Saviozzi S, Calogero R, Papotti M, Scagliotti GV. ERCC1 and RRM1 gene expressions but not EGFR are predictive of shorter survival in advanced non-small-cell lung cancer treated with cisplatin and gemcitabine. Ann Oncol 2006;17(12):181825.

16. Kamal NS, Soria JC, Mendiboure J, Planchard D, Olaussen KA, Rousseau V, Popper H, Pirker R, Bertrand P, Dunant A, Le Chevalier T, Filipits M, Fouret P. MutS homologue 2 and the long-term benefit of adjuvant chemotherapy in lung cancer. Clin Cancer Res 2010;16(4):1206-15.

17. Zhou C, Ren S, Zhou S, Zhang L, Su C, Zhang Z, Su C, Zhang Z, Deng Q, Zhang J. Predictive effects of ERCC1 and XRCC3 SNP on efficacy of platinum-based chemotherapy in advanced NSCLC patients. Jpn J Clin Oncol 2010;40(10):954-60.

18. Ren S, Zhou S, Zhang L, Xu J, Lv M, Zhang J, Zhou C, Zhang J. High-level mRNA of excision repair crosscomplementation group 1 gene is associated with poor outcome of platinum-based doublet chemotherapy of advanced nonsmall cell lung cancer patients. Cancer Invest 2010;28(10):1078-83.

19. Chen S, Zhang J, Wang R, Luo X, Chen H. The platinumbased treatments for advanced non-small cell lung cancer, is low/negative ERCC1 expression better than high/ positive ERCC1 expression? A meta-analysis. Lung Cancer 2010;70(1):63-70.

20. Vilar E, Mukherjee B, Kuick R, Raskin L, Misek DE, Taylor JM, Giordano TJ, Hanash SM, Fearon ER, Rennert $\mathrm{G}$, Gruber SB. Gene expression patterns in mismatch repair-deficient colorectal cancers highlight the potential therapeutic role of inhibitors of the phosphatidylinositol 3-kinase-AKT-mammalian target of rapamycin pathway. Clin Cancer Res 2009;15(8):2829-39.

21. Zheng Z, Chen T, Li X, Haura E, Sharma A, Bepler G. DNA synthesis and repair genes RRM1 and ERCC1 in lung cancer. New Engl J Med 2007;356(8):800-8.

22. Saviozzi S, Ceppi P, Novello S, Ghio P, Lo Iacono M, Borasio P, Cambieri A, Volante M, Papotti M, Calogero RA, Scagliotti GV. Non-small cell lung cancer exhibits transcript overexpression of genes associated with homologous recombination and DNA replication pathways. Cancer Res 2009;69(8):3390-6.

23. Chen C, Hua H, Han C, Cheng Y, Cheng Y, Wang Z, Bao J. Prognosis value of MGMT promoter methylation for patients with lung cancer: a meta-analysis. Int J Clin Exp Pathol 2015;8(9):11560-4.

24. Filipits M, Pirker R. Predictive markers in the adjuvant therapy of non-small cell lung cancer. Lung Cancer 2011;74(3):355-63.

25. Levallet G, Bergot E, Antoine M, Creveuil C, Santos AO, Beau-Faller M, de Fraipont F, Brambilla E, Levallet J, Morin F, Westeel V, Wislez M, Quoix E. et al. High TUBB3 expression, an independent prognostic marker in 
patients with early non-small cell lung cancer treated by preoperative chemotherapy, is regulated by K-Ras signaling pathway. Mol Cancer Therap 2012;11(5):1203-13.

26. de Fraipont F, Levallet G, Creveuil C, Bergot E, BeauFaller M, Mounawar M, Richard N, Antoine M, Rouquette I, Favrot MC, Debieuvre D, Braun D, Westeel V. et al. An apoptosis methylation prognostic signature for early lung cancer in the IFCT-0002 trial. Clin Cancer Res 2012;18(10):2976-86.

27. Gyorffy B, Surowiak P, Budczies J, Lanczky A. Online survival analysis software to assess the prognostic value of biomarkers using transcriptomic data in non-smallcell lung cancer. . 2013;12(e82241):doi: 10.1371/journal. pone.0082241.

28. Zundelevich A, Elad-Sfadia G, Haklai R, Kloog Y. Suppression of lung cancer tumor growth in a nude mouse model by the Ras inhibitor salirasib (farnesylthiosalicylic acid). Mol Cancer Ther 2007;6(6):1765-73.

29. Fabbri M, Iliopoulos D, Trapasso F, Aqeilan RI, Cimmino A, Zanesi N, Yendamuri S, Han SY, Amadori D, Huebner $\mathrm{K}$, Croce CM. WWOX gene restoration prevents lung cancer growth in vitro and in vivo. Proc Natl Acad Sci U S A 2005;102(43):15611-6.

30. Dong F, Guo W, Zhang L, Wu S, Teraishi F, Davis JJ, Fang B. Downregulation of XIAP and induction of apoptosis by the synthetic cyclin-dependent kinase inhibitor GW8510 in non-small cell lung cancer cells. Cancer Biol Ther 2006;5(2):165-70.

31. Olson JM, Hallahan AR. p38 MAP kinase: a convergence point in cancer therapy. Trends Mol Med 2004;10(3):125-9.

32. Planchard D, Camara-Clayette V, Dorvault N, Soria JC, Fouret P. p38 Mitogen-activated protein kinase signaling, ERCC1 expression, and viability of lung cancer cells from never or light smoker patients. Cancer 2012;118(20):501525.

33. Ko JC, Chiu HC, Wo TY, Huang YJ, Tseng SC, Huang YC, Chen HJ, Syu JJ, Chen CY, Jian YT, Jian YJ, Lin YW. Inhibition of p38 MAPK-dependent MutS homologue-2 (MSH2) expression by metformin enhances gefitinibinduced cytotoxicity in human squamous lung cancer cells. Lung Cancer 2013;82(3):397-406.

34. Shaw RJ, Kosmatka M, Bardeesy N, Hurley RL, Witters LA, DePinho RA, Cantley LC. The tumor suppressor LKB1 kinase directly activates AMP-activated kinase and regulates apoptosis in response to energy stress. Proc Natl Acad Sci U S A 2004;101(10):3329-35.

35. Wang Y, Qin J. MSH2 and ATR form a signaling module and regulate two branches of the damage response to DNA methylation. Proc Natl Acad Sci U S A 2003;100(26):15387-92.

36. Cooper WA, Kohonen-Corish MR, Chan C, Kwun SY, McCaughan B, Kennedy C, Sutherland RL, Lee CS. Prognostic significance of DNA repair proteins MLH1, MSH2 and MGMT expression in non-small-cell lung cancer and precursor lesions. Histopathology 2008;52(5):613-22.

37. Friboulet L, Olaussen KA, Pignon JP, Shepherd FA, Tsao MS, Graziano S, Kratzke R, Douillard JY, Seymour L, Pirker R, Filipits M, Andre F, Solary E, et al. ERCC1 isoform expression and DNA repair in non-small-cell lung cancer. N Engl J Med 2013;368(12):1101-10.

38. Taron M, Rosell R, Felip E, Mendez P, Souglakos J, Ronco MS, Queralt C, Majo J, Sanchez JM, Sanchez JJ, Maestre J. BRCA1 mRNA expression levels as an indicator of chemoresistance in lung cancer. Hum Mol Genet 2004;13(20):2443-9.

39. Pierceall WE, Olaussen KA, Rousseau V, Brambilla E, Sprott KM, Andre F, Pignon JP, Le Chevalier T, Pirker R, Jiang C, Filipits M, Chen Y, Kutok JL, et al. Cisplatin benefit is predicted by immunohistochemical analysis of DNA repair proteins in squamous cell carcinoma but not adenocarcinoma: theranostic modeling by NSCLC constituent histological subclasses. Ann Oncol 2012;23(9):2245-52.

40. Levra MG, Olaussen KA, Novello S, Soria JC. PARP inhibitors: an interesting pathway also for non-small cell lung cancer? Curr Pharm Des. 2014;20 :3875-82

41. Esteller M, Hamilton SR, Burger PC, Baylin SB, Herman JG. Inactivation of the DNA repair gene O6-methylguanineDNA methyltransferase by promoter hypermethylation is a common event in primary human neoplasia. Cancer Res 1999;59(4):793-7.

42. Liu F, Killian JK, Yang M, Walker RL, Hong JA, Zhang M, Davis S, Zhang Y, Hussain M, Xi S, Rao M, Meltzer PA, Schrump DS. Epigenomic alterations and gene expression profiles in respiratory epithelia exposed to cigarette smoke condensate. Oncogene 2010;29(25):3650-64.

43. Harrell FJ, Lee K, Mark D. Multivariable prognostic models: issues in developing models, evaluating assumptions and adequacy, and measuring and reducing errors. Stat Med 1996;15:361-87. 